\title{
СИНТЕЗ ТА АНТИМІКРОБНІ ВЛАСТИВОСТІ 5-(4-R-БЕНЗИЛ)-2-ТІАЗОЛІЛАМІДІВ 5-АРИЛІДЕНРОДАНІН-3-АЛКАНКАРБОНОВИХ КИСЛОТ
}

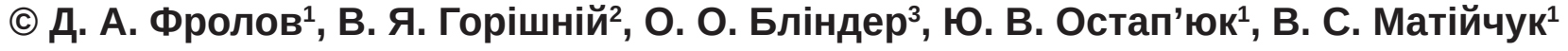 \\ Львівський національний університет імені Івана Франка ${ }^{1}$ \\ Львівський національний медичний університет імені Данила Галицького ${ }^{2}$ \\ ВДНЗ України «Буковинський державний медичний університет»³ \\ matichyk@mail.Iviv.ua
}

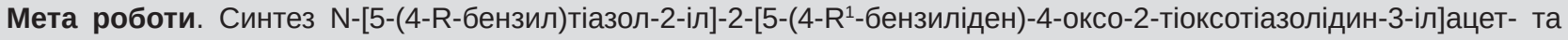
пропіонамідів із наступним дослідженням їх антимікробної активності.

Матеріали і методи. При виконанні експериментальної частини роботи використано традиційні методи органічного синтезу. Вихідні реагенти синтезовані за відомими методиками із комерційно доступних реактивів. Спектри ЯMP одержаних сполук знімали на приладі Varian VXR-400, розчинник DMSO-d ${ }_{6}$, стандарт - тетраметилсилан. Антимікробну активність отриманих сполук вивчали за допомогою мікрометоду 3 використанням одноразових 96-лункових стерильних полістиролових планшетів та мікротитраторів Такачі.

Результати й обговорення. Взаємодією 5-(4-R-бензил)-1,3-тіазол-2-амінів 1a-c 3 хлорангідридами (5-R ${ }^{1}$ бензиліден-4-оксо-2-тіоксотіазолідин-3-іл)оцтових 2a-c та пропіонових 3a-с кислот отримано ряд нових амідів 9а-і та 10a-i. Досліджено їх антимікробну активність. Встановлено, що сполуки 9а та 10h проявляють високу активність по відношенню до S.aureus ATCC № 25923.

Висновки. Вперше отримано низку N-[5-(4-R-бензил)тіазол-2-іл]-2-[5-(4-R ${ }^{1}$-бензиліден)-4-оксо-2-тіоксотіазолідин3-іл]ацет- 9а-і і пропіонамідів 10а-і та досліджено in vitro їх антимікробну активність.

Знайдено сполуки, що володіють високою активністю по відношенню до S.aureus ATCC № 25923.

Ключові слова: тіазол; 2-тіоксотіазолідин-4-он; хлороарилювання; антимікробна активність.
\end{abstract}

Вступ. Похідні 2-амінотіазолу широко відомі як біологічно активні сполуки. Серед цього класу знайдено речовини, що володіють протипухлинною, протизапальною, противірусною, протимікробною, нейропротекторною та іншими видами активності [1-4]. Ряд таких сполук використовується як лікарські препарати. Це, зокрема, такі відомі препарати, як фрамотидин, абафрунгін, цесдинір, судоксикам, мелоксикам, праміпексол [5]. На сьогодні 2-амінотіазольний фррагмент прийнято вважати привілейованою структурою в медичній хімії. Іншим важливим похідним тіазолу є 2-тіоксотіазолідин-4-он (роданін). Як і 2-амінотіазольний, даний гетероцикл також розглядається як привілейований [6]. Зважаючи на це, вважаємо актуальним поєднання цих двох гетероциклів в одній молекулі та пошук серед отриманих гібридів біологічно активних речовин.
Матеріали і методи. При виконанні експериментальної частини роботи використані традиційні методи органічного синтезу. Спектри ЯМР одержаних сполук знімались на приладі Varian VXR-400, розчинник

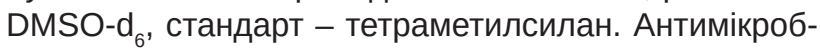
ну активність отриманих сполук вивчали за допомогою мікрометоду з використанням одноразових 96-лункових стерильних полістиролових планшетів та мікротитраторів Такачі.

Результати й обговорення. У роботі описано синтез та дослідження антимікробних властивостей N-[5-(4-R-бензил)тіазол-2-іл]-2-[5-(4-R ${ }^{1}$-бензиліден)4-оксо-2-тіоксотіазолідин-3-іл]ацет- 9а-і та пропіонамідів 10а-і. Вихідними речовинамии для їх отримання слугували 5-(4-R-бензил)-1,3-тіазол-2-аміни 1a-c, (5-бензиліден-4-оксо-2-тіоксотіазолідин-3-іл)оцтові 2а-с та пропіонові За-с кислоти. 
Синтез біологічно активних сполук

Synthesis of biologically active compounds<smiles>[R]c1ccc(Cc2cnc(N)s2)cc1</smiles>

1a-c<smiles>[R]c1ccc(/C=C2\SC(=S)N(CC(=O)O)C2=O)cc1</smiles>

2a-c<smiles>[R]c1ccc(/C=C2\SC(=S)N(CCC(=O)O)C2=O)cc1</smiles>

3a-c

1a-c $\mathrm{R}=\mathrm{H}(\mathbf{a}), \mathrm{CH}_{3}(\mathbf{b}), \mathrm{Cl}(\mathbf{c}) ; \mathbf{2} \mathbf{a}-\mathbf{c}, \mathbf{3} \mathbf{a}-\mathbf{c} \mathrm{R}^{1}=\mathrm{H}(\mathbf{a}), \mathrm{CH}_{3}(\mathbf{b}), \mathrm{Cl}(\mathbf{c})$.

Аміни 1а-с синтезували взаємодією 3-арил-2хлоропропаналів 4а-с 3 тіосечовиною [7]. 3-Арил-2- хлоропропаналі 4а-с, у свою чергу, отримано хлороарилюванням акролеїну арендіазонієвими солями.
N<smiles>[R]CCCC(=O)C=C</smiles><smiles>[R]c1ccc(CC(Cl)C=O)cc1</smiles>

1)<smiles>NC(=S)N[O+]([O-])O</smiles><smiles>[R]c1ccc(Cc2cnc(N)s2)cc1</smiles>

4à-ñ

Вихідними речовинами для синтезу 5-ариліден2-тіоксо-4-тіазолідинон-3-алканкарбонових кислот 2a-c і За-с слугували 2-амінооцтова та 3-амінопропіонова кислоти. Їх дитіокарбамінантним методом було перетворено у відповідні (4-оксо-2тіоксотіазолідин-3-іл)оцтову 5 та пропіонову 6 кислоти. Реакцією Кньовенагеля 5 і 6 з ароматичними альдегідами 7а-с отримували кислоти 2a-c і 3a-c. Цю взаємодію здійснювали класичним методом - в середовищі оцтової кислоти у присутності ацетату натрію. Запропоновані в літературі альтернативні підходи до синтезу кислот не мають жодних переваг, а в деяких випадках містять тільки теоретичний інтерес [8-10].

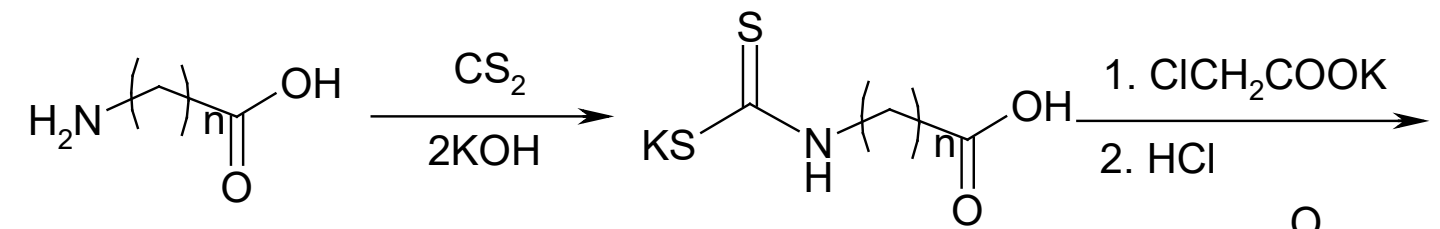<smiles>[R]c1ccc(C=O)cc1</smiles>

5,6

$5 n=1,6 n=2$.

2a-c, 3a-c 
3 метою активування карбоксильної фрункції 5-ариліден-2-тіоксо-4-тіазолідон-3-алканкарбонових кислот 2a-c та 3а-с вони були перетворені у відповідні хлорангідриди. Для цього їх кип'ятили в суміші тіо-<smiles>[R]c1ccc(/C=C2\SC(=S)N(C(C)(C)C(=O)O)C2=O)cc1</smiles>

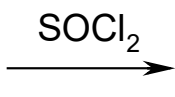

Цільові аміди 9а-і і 10а-і отримано взаємодією амінів 1а-с 3 хлорангідридами кислот 7а-с та 8а-с. Реак- нілхлориду та безводного бензолу або толуолу. Закінченням реакції вважалось повне розчинення вихідних речовин. Одержані хлорангідриди виділялись осадженням петролейним ефріром.<smiles>[R]c1ccc(/C=C2\SC(=S)N(CC(C)(C)C(=O)Cl)C2=O)cc1</smiles>

цію проводили в середовищі діоксану в присутності триетиламіну як основи.<smiles>[R]c1ccc(/C=C2\SC(=S)N(CC(=O)Nc3ncc(Cc4ccccc4)s3)C2=O)cc1</smiles><smiles></smiles><smiles>[R]COC(=O)CCN1C(=O)/C(=C/c2ccc([R7])cc2)SC1=S</smiles>

$10 a-i$

9a-i, 10a-i R = H, R ${ }^{1}=\mathrm{H}(\mathbf{a}), \mathrm{CH}_{3}(\mathbf{b}), \mathrm{Cl}(\mathbf{c})$, $\mathrm{R}=\mathrm{CH}_{3}, \mathrm{R}^{1}=\mathrm{H}(\mathbf{d}), \mathrm{CH}_{3}(\mathbf{e}), \mathrm{Cl}(\mathbf{f})$, $\mathrm{R}=\mathrm{Cl}, \mathrm{R}^{1}=\mathrm{H}(\mathbf{g}), \mathrm{CH}_{3}(\mathbf{h}), \mathrm{Cl}(\mathbf{i})$.

Отримані аміди високоплавкі речовини жовтого або жовто-оранжевого кольору, добре розчинні в полярних органічних розчинниках. Їх будова доведена за допомогою ${ }^{1} \mathrm{H}$ ЯМР спектроскопії. Зокрема, сигнали метиленових груп спостерігали при 4,93 - 4, 94 м. д. та 4,01 - 4,09 м. д., амідних протонів 12,48 - 12,53 м. д. (сполуки 9а-і) та 12,06 - 12,11 м. д. (10a-i).

Антимікробну активність вивчали щодо п'яти штамів бактерій (E. coli ATCC 25928, P.mirabilis 410, S.

aureus ATCC № 25923, P.aeruginosa ATCC № 27853, B.subtilis ATCC № 6633) та двох мікроскопічних грибків (C.albicans, S.cerevisiae 61). E. coli ATCC 25928 та P.mirabilis 410 належать до родини ентеробактерій i можуть викликати інфекційні захворювання шлунково-кишкового тракту людини. Золотистий стафілокок S.aureus ATCC № 25923 часто є причиною гнійно-запальних захворювань. На відміну від попередніх штамів, які є грамнегативними, він належить до грам- 
Синтез біологічно активних сполук

Synthesis of biologically active compounds

позитивних бактерій. Псевдомонади P.aeruginosa ATCC № 27853 часто зустрічаються у навколишньому середовищі, але можуть спричиняти захворювання в імуноскомпрометованих людей. Штам B.subtilis ATCC № $6633 €$ сапрофрітом, який не завдає шкоди здоров'ю людини. Але він здатний утворювати спори, як і деякі високопатогенні для людини бактерії. С. albicans та S.cerevisiae 61 належать до мікроскопічних грибків. Кандіди (C.albicans) є патогенними для людини, а сахароміцети (S.cerevisiae) належать до «істинних» грибів і не патогенні.

У результаті досліджень антимікробної активності встановлено, що синтезовані сполуки у відношенні до грамнегативних тест-штамів бактерій (кишкової палички, протею та псевдомонад), а також у відношенні до штаму B.subtilis ATCC № 6633, активності не виявляють, або вона спостерігається тільки при найвищій вивченій конецентрації - 500 мкг/мл. Висока антибактеріальна активність у відношенні до стафрілококу виявлена у речовин 9a та 10h. Помітна активність у відношенні до цього ж штаму спостерігалася для речовини 10i. Цікавий фракт - речовина 9a мала так звану парадоксальну дію. Тобто, концетрація 500 мкг/мл проявляла антибактеріальну дію. В інтервалі концентрацій 250-31,3 мкг/мл дії не було, а нижчі концентрації (аж до 3,9 мкг/мл включно) знову виявляли антибактеріальну дію.

Висновки. Вперше отримано низку N-[5-(4-Rбензил)тіазол-2-іл]-2-[5-(4-R ${ }^{1}$-бензиліден)-4-оксо-2тіоксотіазолідин-3-іл]ацет- та пропіонамідів і досліджено in vitro їх антимікробну активність.

Знайдено сполуки, що володіють високою активністю по відношенню до S.aureus ATCC № 25923.

\section{Експериментальна частина}

Загальна методика одержання (5-ариліден-4оксо-2-тіоксотіазолідин-3-іл)алканкарбонових кислот 2a-c, 3a-c

У круглодонну колбу зі зворотним холодильником поміщають 50 ммоль 2-тіоксо-4-тіазолідон-3алканкарбонової кислоти, 60 ммоль відповідного заміщеного бензальдегіду, 50 ммоль безводного натрію ацетату і 50 мл кислоти ацетатної. Реакційну суміш кип'ятять протягом 3-х годин. Охолоджують, продукт реакції відфільтровують, промивають ацетатною кислотою, водою, висушують і перекристалізовують 3 суміші ДМФА - ацетатна кислота.

(5-Бензиліден-4-оксо-2-тіоксотіазолідин-3-іл) оцтова кислота 2a. Вихід $78 \%$. Т.пл 235-237 ${ }^{\circ} \mathrm{C}$. Спектр ЯМР ${ }^{1} \mathrm{H}\left(400 \mathrm{MHz}\right.$, DMSO-d $\left.{ }_{6}\right) \delta: 13.47 \mathrm{c}(1 \mathrm{H}$, $\mathrm{COOH}), 7.91$ с $(1 \mathrm{H},=\mathrm{CH}), 7.68$ д $\left(2 \mathrm{H}, \mathrm{J}=6.5 \mathrm{~Hz}, \mathrm{C}_{6} \mathrm{H}\right)$, $7.61-7.50 \mathrm{~m}\left(3 \mathrm{H}, \mathrm{C}_{6} \mathrm{H}_{5}\right), 4.75 \mathrm{c}\left(2 \mathrm{H}, \mathrm{CH}_{2}\right)$.

[ 5 - ( 4 - М е т и лбе н $з$ и л і де н ) - 4 - о к с о - 2 тіоксотіазолідин-3-іл]оцтова кислота 2b. Вихід $82 \%$. Т.пл. > $260^{\circ} \mathrm{C}$. Спектр ЯМР ${ }^{1} \mathrm{H}(400 \mathrm{MHz}$, DMSO-d $)_{6}$ : 7.81 с $(1 \mathrm{H},=\mathrm{CH}), 7.55$ д $(2 \mathrm{H}, \mathrm{J}=7.9 \mathrm{~Hz}$, $\left.\mathrm{C}_{6} \mathrm{H}_{4}\right), 7.38$ д $\left(2 \mathrm{H}, \mathrm{J}=7.9 \mathrm{~Hz}, \mathrm{C}_{6} \mathrm{H}_{4}\right), 4.61 \mathrm{c}\left(2 \mathrm{H}, \mathrm{CH}_{2}\right)$, $2.37 \mathrm{C}\left(3 \mathrm{H}, \mathrm{CH}_{3}\right)$.
[ 5 - ( 4 - Х л о р о б е н з и л і д н ) - 4 - о к с о - 2 тіоксотіазолідин-3-іл]оцтова кислота 2с. Вихід 79 \%. Т.пл. $258-260{ }^{\circ} \mathrm{C}$. Спектр ЯМР ${ }^{1} \mathrm{H}(400 \mathrm{MHz}$, DMSO-d $\left.{ }_{6}\right) \delta: ~ 14.02-13.14$ ш.с $(1 \mathrm{H}, \mathrm{COOH}), 7.90 \mathrm{c}(1 \mathrm{H}$, $=\mathrm{CH}), 7.70$ д $\left(2 \mathrm{H}, \mathrm{J}=8.4 \mathrm{~Hz}, \mathrm{C}_{6} \mathrm{H}_{4}\right), 7.63$ д $(2 \mathrm{H}, \mathrm{J}=8.5$ $\left.\mathrm{Hz}, \mathrm{C}_{6} \mathrm{H}_{4}\right), 4.74 \mathrm{C}\left(2 \mathrm{H}, \mathrm{CH}_{2}\right)$.

3-(-(5-Бензиліден-4-оксо-2-тіоксотіазолідин-3іл)пропанова кислота За. Вихід 73 \%. Т.пл. 178$180{ }^{\circ} \mathrm{C}$. Спектр ЯМР ${ }^{1} \mathrm{H}\left(400 \mathrm{MHz}, \mathrm{DMSO}-\mathrm{d}_{6}\right) \delta: 12.77$ -12.07 ш.с $(1 \mathrm{H}, \mathrm{COOH}), 7.82$ с $(1 \mathrm{H},=\mathrm{CH}), 7.64$ д $(2 \mathrm{H}$, $\left.\mathrm{J}=7.0 \mathrm{~Hz}, \mathrm{C}_{6} \mathrm{H}_{5}\right), 7.61-7.46 \mathrm{M}\left(3 \mathrm{H}, \mathrm{C}_{6} \mathrm{H}_{5}\right), 4.23 \mathrm{~T}(2 \mathrm{H}$, $\left.\mathrm{J}=7.7 \mathrm{~Hz}, \mathrm{CH}_{2}\right), 2.64 \mathrm{~T}\left(2 \mathrm{H}, \mathrm{J}=7.7 \mathrm{~Hz}, \mathrm{CH}_{2}\right)$.

3-[5-(4-Метилбензиліден)-4-оксо-2тіоксотіазолідин-3-іл]пропанова кислота 3b. Вихід 76 \%. Т.пл. $152-153^{\circ} \mathrm{C}$. Спектр ЯМР ${ }^{1} \mathrm{H}(400 \mathrm{MHz}$, DMSO-d $\left.{ }_{6}\right) \delta: 12.50 \mathrm{c}(1 \mathrm{H}, \mathrm{COOH}), 7.77 \mathrm{c}(1 \mathrm{H},=\mathrm{CH})$, 7.52 д $\left(2 \mathrm{H}, J=8.1 \mathrm{~Hz}, \mathrm{C}_{6} \mathrm{H}_{4}\right), 7.36$ д $(2 \mathrm{H}, \mathrm{J}=8.0 \mathrm{~Hz}$, $\left.\mathrm{C}_{6} \mathrm{H}_{4}\right), 4.21 \mathrm{~T}\left(2 \mathrm{H}, \mathrm{J}=7.7 \mathrm{~Hz}, \mathrm{CH}_{2}\right), 2.62 \mathrm{~T}(2 \mathrm{H}, \mathrm{J}=$ $\left.7.7 \mathrm{~Hz}, \mathrm{CH}_{2}\right), 2.36 \mathrm{c}\left(1 \mathrm{H}, \mathrm{CH}_{3}\right)$.

3 - [ 5 - ( 4 - Х лор обе н з и ліден ) - 4 - оксо - 2 тіоксотіазолідин-3-іл]пропанова кислота Зс. Вихід 79 \%. Т.пл. 236-237 ${ }^{\circ}$ С.Спектр ЯМР ${ }^{1} \mathrm{H}(400 \mathrm{MHz}$, DMSO-d $\left.{ }_{6}\right) \delta: ~ 13.03$ - 11.99 ш.c $(1 \mathrm{H}, \mathrm{COOH}), 7.81 \mathrm{c}(1 \mathrm{H}$, $=\mathrm{CH}), 7.66$ д $\left(2 \mathrm{H}, \mathrm{J}=8.4 \mathrm{~Hz}, \mathrm{C}_{6} \mathrm{H}_{4}\right), 7.61$ д $(2 \mathrm{H}, \mathrm{J}=8.4$ $\left.\mathrm{Hz}, \mathrm{C}_{6} \mathrm{H}_{4}\right), 4.22 \mathrm{~T}\left(2 \mathrm{H}, \mathrm{J}=7.6 \mathrm{~Hz}, \mathrm{CH}_{2}\right), 2.63 \mathrm{~T}(2 \mathrm{H}, \mathrm{J}=$ $7.6 \mathrm{~Hz}, \mathrm{CH}_{2}$ ).

Загальна методика одержання хлорангідридів (5-ариліден-4-оксо-2-тіоксотіазолідин-3-іл)алканкарбонових кислот 7a-c, 8a-c

У круглодонну колбу зі зворотним холодильником поміщають 50 ммоль 5-ариліден-2-тіоксо-4тіазолідон-3-алканкарбонової кислоти, додають 50 мл безводного бензолу та 25 мл $\mathrm{SOCl}_{2}$ і кип'ятять до повного розчинення. Розчин вливають до 50 мл гексану або петролейного ефіру, утворений осад відфрільтровують і перекристалізовують з бензолу або суміші бензол - гексан.

(5-Бензиліден-4-оксо-2-тіоксотіазолідин-3-іл) ацетил хлорид 7а. Вихід 89 \%. Т.пл. 140-141 ${ }^{\circ} \mathrm{C}$.

[ 5 - ( 4 - М е т и л б е н $з$ и лі де н ) - 4 - о к с о - 2 тіоксотіазолідин-3-іл]ацетил хлорид 7b. Вихід \%. Т.пл. $145-147^{\circ} \mathrm{C}$.

[ 5 - ( 4 - Х ло р о бе н 3 и л і де н ) - 4 - о к с о - 2 тіоксотіазолідин-3-іл]ацетил хлорид 7с. Вихід 88 \%. Т.пл. $141-143^{\circ} \mathrm{C}$.

3-(5-Бензиліден-4-оксо-2-тіоксотіазолідин-3-іл) пропіоніл хлорид 8а. Вихід 99 \%. Т.пл. 105-106 ${ }^{\circ} \mathrm{C}$.

3 - [ 5 - ( 4 - Ме т и лбе н 3 и лі де н ) - 4 - о к с о - 2 тіоксотіазолідин-3-іл]пропіоніл хлорид 8b. Вихід $99 \%$. Т.пл. $152-153^{\circ} \mathrm{C}$.

3 - [ 5 - ( 4 - Х лор обе н 3 и ліден ) - 4 - о ксо - 2 тіоксотіазолідин-3-іл]пропіоніл хлорид 8с. Вихід 96 \%. Т.пл. $156-158{ }^{\circ} \mathrm{C}$.

Загальна методика синтезу амідів 9a-i, 10f-i

До розчину 0.01 моль 5-(4-R-бензил)-1,3-тіазол-2аміну 1a-c та 1.5 мл триетиламіну в 15 мл діоксану додавали розчин 0.01 моль відповідного хлорангі-

ISSN 2312-0967. Фармацевтичний часопис. 2017. № 3 
дриду в 20 мл діоксану. Залишали на 1 год. Реакційну суміш виливали в 100 мл води. Осад, що утворився, фрільтрували та перекристалізовували із суміші ДМФА - ацетатна кислота.

2-(5-Бензиліден-4-оксо-2-тіоксотіазолідин-3іл)-N-(5-бензилтіазол-2-іл)-ацетамід 9a. Вихід $91 \%$. Т.пл . 229-231 ${ }^{\circ} \mathrm{C}$. Спектр ЯМР ${ }^{1} \mathrm{H}(400 \mathrm{MHz}$, DMSO-d $\left.{ }_{6}\right) \delta: 12.50$ с $(1 \mathrm{H}, \mathrm{NH}), 7.88$ с $(1 \mathrm{H},=\mathrm{CH}), 7.67$ д $\left(2 \mathrm{H}, \mathrm{J}=6.1 \mathrm{~Hz}, \mathrm{C}_{6} \mathrm{H}_{5}\right), 7.58-7.53 \mathrm{M}\left(3 \mathrm{H}, \mathrm{C}_{6} \mathrm{H}_{5}\right), 7.30-$ $7.19 \mathrm{M}\left(6 \mathrm{H}, \mathrm{C}_{6} \mathrm{H}_{5}, 4-\mathrm{H}_{\text {тізоло }}\right), 4.94 \mathrm{c}\left(2 \mathrm{H}, \mathrm{CH}_{2}\right), 4.07 \mathrm{c}(2 \mathrm{H}$, $\left.\mathrm{CH}_{2}\right)$.

N - ( 5 - б е н 3 и л т і а з о л - 2 - і л ) - 2 - [ 5 - ( 4 метилбензиліден)-4-оксо-2-тіоксотіазолідин-3-іл] ацетамід 9b. Вихід 86\%. Тпл > $260{ }^{\circ} \mathrm{C}$. Спектр ЯМР ${ }^{1} \mathrm{H}\left(400 \mathrm{MHz}, \mathrm{DMSO}-\mathrm{d}_{6}\right) \delta: 12.50 \mathrm{c}(1 \mathrm{H}, \mathrm{NH}), 7.85 \mathrm{c}(1 \mathrm{H}$, $=\mathrm{CH}), 7.57$ д $(2 \mathrm{H}, \mathrm{J}=7.8 \mathrm{~Hz}, \mathrm{C} 6 \mathrm{H} 4), 7.39$ д $(2 \mathrm{H}, \mathrm{J}=7.7$ $\left.\mathrm{Hz}, \mathrm{C}_{6} \mathrm{H}_{4}\right), 7.34-7.16 \mathrm{~m}\left(6 \mathrm{H}, \mathrm{C}_{6} \mathrm{H}_{5}, 4-\mathrm{H}_{\text {тізоло }}\right), 4.93 \mathrm{c}(2 \mathrm{H}$, $\mathrm{CH} 2), 4.07 \mathrm{c}\left(2 \mathrm{H}, \mathrm{CH}_{2}\right), 2.38 \mathrm{c}\left(3 \mathrm{H}, \mathrm{CH}_{3}\right)$.

N - ( 5 - б е н 3 и л т і а $з$ о л - 2 - і л ) - 2 - [ 5 - ( 4 хлоробензиліден)-4-оксо-2-тіоксотіазолідин-3-іл] ацетамід 9с. Вихід 88 \%. Т.пл. 263-265 ${ }^{\circ} \mathrm{C}$. Спектр ЯMP ${ }^{1} \mathrm{H}\left(400 \mathrm{MHz}, \mathrm{DMSO}-\mathrm{d}_{6}\right) \delta: 12.52 \mathrm{c}(1 \mathrm{H}, \mathrm{NH}), 7.91$ c $(1 \mathrm{H},=\mathrm{CH}), 7.72$ д $\left(2 \mathrm{H}, \mathrm{J}=8.5 \mathrm{~Hz}, \mathrm{C}_{6} \mathrm{H}_{4}\right), 7.66$ д $(2 \mathrm{H}, \mathrm{J}$ $\left.=8.6 \mathrm{~Hz}, \mathrm{C}_{6} \mathrm{H}_{4}\right), 7.36-7.18 \mathrm{~m}\left(6 \mathrm{H}, \mathrm{C}_{6} \mathrm{H}_{5}, 4-\mathrm{H}_{\text {тіазол }}\right), 4.96$ $\mathrm{C}\left(2 \mathrm{H}, \mathrm{CH}_{2}\right), 4.09 \mathrm{c}\left(2 \mathrm{H}, \mathrm{CH}_{2}\right)$.

2-(5-Бензиліден-4-оксо-2-тіоксотіазолідин-3іл)-N-[5-(4-метилбензил)-тіазол-2-іл]ацетамід 9d. Вихід 96 \%. Т.пл. $231-233^{\circ} \mathrm{C}$. Спектр ЯМР ${ }^{1} \mathrm{H}(400$ $\left.\mathrm{MHz}, \mathrm{DMSO}-\mathrm{d}_{6}\right) \delta: 12.48 \mathrm{c}(1 \mathrm{H}, \mathrm{NH}), 7.88 \mathrm{c}(1 \mathrm{H},=\mathrm{CH})$, 7.67 д $\left(2 \mathrm{H}, \mathrm{J}=7.0 \mathrm{~Hz}, \mathrm{C}_{6} \mathrm{H}_{5}\right), 7.64-7.45 \mathrm{м}\left(3 \mathrm{H}, \mathrm{C}_{6} \mathrm{H}_{5}\right)$, $7.24 \mathrm{c}\left(1 \mathrm{H}, 4-\mathrm{H}_{\text {тізол }}\right), 7.11 \mathrm{д}\left(2 \mathrm{H}, \mathrm{J}=8.2 \mathrm{~Hz}, \mathrm{C}_{6} \mathrm{H}_{4}\right), 7.09$ д $\left(2 \mathrm{H}, \mathrm{J}=8.0 \mathrm{~Hz}, \mathrm{C}_{6} \mathrm{H}_{4}\right), 4.93 \mathrm{c}\left(2 \mathrm{H}, \mathrm{CH}_{2}\right), 4.01 \mathrm{c}(2 \mathrm{H}$, $\left.\mathrm{CH}_{2}\right), 2.24 \mathrm{C}\left(3 \mathrm{H}, \mathrm{CH}_{3}\right)$.

2 - [ 5 - ( 4 - Ме т и лбе н $з$ и ліден ) - 4 - о ксо - 2 тіоксотіазолідин-3-іл]-N-[5-(4-метилбензил)тіазол-2-іл]ацетамід 9е. Вихід 96 \%. Т.пл. 234$237^{\circ} \mathrm{C}$. Спектр ЯМР ${ }^{1} \mathrm{H}(400 \mathrm{MHz}$, DMSO-d $)$ ס: 12.48 (c, 1H, NH), 7.84 (c, 1H, =CH), 7.57 (д, J = 7.6 Hz, 2H, $\left.\mathrm{C}_{6} \mathrm{H}_{4}\right), 7.39$ (д, J = 7.5 Hz, 2H, $\left.\mathrm{C}_{6} \mathrm{H}_{4}\right), 7.25$ (с, $1 \mathrm{H}, \mathrm{H}_{\text {тіазол }}$ ), 7.11 (ш.c, 4H, C $\mathrm{H}_{4}$ ), 4.93 (c, $2 \mathrm{H}, \mathrm{CH}_{2}$ ), 4.01 (c, $2 \mathrm{H}$, $\left.\mathrm{CH}_{2}\right), 2.37\left(\mathrm{c}, 3 \mathrm{H}, \mathrm{CH}_{3}\right), 2.24\left(\mathrm{c}, 3 \mathrm{H}, \mathrm{CH}_{3}\right)$.

2 - [ 5 - ( 4 - Х ло р обе н $з$ и лі де н ) - 4 - о к с о - 2 тіоксотіазолідин-3-іл]-N-[5-(4-метилбензил)тіазол-2-іл]ацетамід 9f. Вихід 93 \%. Т.пл. 234$-236{ }^{\circ} \mathrm{C}$. Спектр ЯMP ${ }^{1} \mathrm{H}\left(400 \mathrm{MHz}, \mathrm{DMSO}^{-\mathrm{d}_{6}}\right) \delta: 12.49$ с $(1 \mathrm{H}, \mathrm{NH}), 7.89$ с $(1 \mathrm{H},=\mathrm{CH}), 7.70$ д $(2 \mathrm{H}, \mathrm{J}=8.5 \mathrm{~Hz}$, $\left.\mathrm{ClC}_{6} \mathrm{H}_{4}\right), 7.64$ д $\left(2 \mathrm{H}, \mathrm{J}=8.5 \mathrm{~Hz}, \mathrm{ClC}_{6} \mathrm{H}_{4}\right), 7.25 \mathrm{c}(1 \mathrm{H}$, $\left.4-\mathrm{H}_{\text {тіазол }}\right), 7.12$ д $\left(2 \mathrm{H}, \mathrm{J}=8.3 \mathrm{~Hz}, \mathrm{MeC}_{6} \mathrm{H}_{4}\right), 7.09$ д $(2 \mathrm{H}, \mathrm{J}$ $\left.=8.4 \mathrm{~Hz}, \mathrm{MeC}_{6} \mathrm{H}_{4}\right), 4.93 \mathrm{c}\left(2 \mathrm{H}, \mathrm{CH}_{2}\right), 4.02 \mathrm{c}\left(2 \mathrm{H}, \mathrm{CH}_{2}\right)$, $2.25 \mathrm{C}\left(3 \mathrm{H}, \mathrm{CH}_{3}\right)$.

2-(5-Бензиліден-4-оксо-2-тіоксотіазолідин-3іл)-N-[5-(4-хлоробензил)-тіазол-2-іл]ацетамід $9 \mathrm{~g}$. Вихід 86 \%. Т.пл. $252-254^{\circ} \mathrm{C}$. Спектр ЯМР ${ }^{1} \mathrm{H}(400$ $\left.\mathrm{MHz}, \mathrm{DMSO}-\mathrm{d}_{6}\right) \delta: 12.52 \mathrm{c}(1 \mathrm{H}, \mathrm{NH}), 7.88 \mathrm{c}(1 \mathrm{H},=\mathrm{CH})$, 7.68 д (2H, J = 6.0 Hz, Ar), $7.60-7.54$ м (3H, Ar), 7.35д $(2 \mathrm{H}, \mathrm{J}=7.4 \mathrm{~Hz}, \mathrm{Ar}), 7.30-7.24 \mathrm{~m}\left(3 \mathrm{H}, \mathrm{Ar}, 4-\mathrm{H}_{\text {тіазол }}\right), 4.94$ C $\left(2 \mathrm{H}, \mathrm{CH}_{2}\right), 4.08 \mathrm{C}\left(2 \mathrm{H}, \mathrm{CH}_{2}\right)$.
N-[5-(4-хлоробензил)-тіазол-2-іл]-2-[5-(4метилбензиліден)-4-оксо-2-тіоксотіазолідин-3-іл] ацетамід 9h. Вихід 93 \%. Т.пл. 234-236 ${ }^{\circ} \mathrm{C}$. Спектр ЯMP ${ }^{1} \mathrm{H}\left(400 \mathrm{MHz}, \mathrm{DMSO}-\mathrm{d}_{6}\right) \delta: 12.52 \mathrm{c}(1 \mathrm{H}, \mathrm{NH}), 7.85$ с $(1 \mathrm{H},=\mathrm{CH}), 7.57$ д $\left(2 \mathrm{H}, \mathrm{J}=8.0 \mathrm{~Hz}, \mathrm{MeC}_{6} \mathrm{H}_{4}\right), 7.39$ д $\left(2 \mathrm{H}, J=8.0 \mathrm{~Hz}, \mathrm{MeC}_{6} \mathrm{H}_{4}\right), 7.35$ д $\left(2 \mathrm{H}, \mathrm{J}=8.3 \mathrm{~Hz}, \mathrm{ClC}_{6} \mathrm{H}_{4}\right)$, $7.30-7.25 \mathrm{~m}\left(3 \mathrm{H}, \mathrm{ClC}_{6} \mathrm{H}_{4}, 4-\mathrm{H}_{\text {тіззол }}\right), 4.94 \mathrm{c}\left(2 \mathrm{H}, \mathrm{CH}_{2}\right)$, $4.08 \mathrm{c}\left(2 \mathrm{H}, \mathrm{CH}_{2}\right), 2.38 \mathrm{c}\left(3 \mathrm{H}, \mathrm{CH}_{3}\right)$.

2 - [ 5 - ( 4 - Х ло робе н 3 и ліден ) - 4 - оксо - 2 тіоксотіазолідин-3-іл]-N-[5-(4-хлоробензил)тіазол-2-іл]ацетамід 9і. Вихід 99 \%. Т.пл. 241$243^{\circ} \mathrm{C}$. Спектр ЯMP ${ }^{1} \mathrm{H}\left(400 \mathrm{MHz}, \mathrm{DMSO}_{-} \mathrm{d}_{6}\right) \delta: 12.53$ с $(1 \mathrm{H}, \mathrm{NH}), 7.89$ с $(1 \mathrm{H},=\mathrm{CH}), 7.70$ д $(2 \mathrm{H}, \mathrm{J}=8.6 \mathrm{~Hz}$, $\left.\mathrm{C}_{6} \mathrm{H}_{4}\right), 7.63$ д $\left(2 \mathrm{H}, \mathrm{J}=8.6 \mathrm{~Hz}, \mathrm{C}_{6} \mathrm{H}_{4}\right), 7.35$ д $(2 \mathrm{H}, \mathrm{J}=8.3$ $\left.\mathrm{Hz}, \mathrm{C}_{6} \mathrm{H}_{4}\right), 7.29 \mathrm{c}\left(1 \mathrm{H}, 4-\mathrm{H}_{\text {тіазол }}\right), 7.27$ д $(2 \mathrm{H}, \mathrm{J}=8.7 \mathrm{~Hz}$, $\left.\mathrm{C}_{6} \mathrm{H}_{4}\right), 4.94 \mathrm{c}\left(2 \mathrm{H}, \mathrm{CH}_{2}\right), 4.08 \mathrm{c}\left(2 \mathrm{H}, \mathrm{CH}_{2}\right)$.

3-(5-Бензиліден-4-оксо-2-тіоксотіазолідин-3іл)-N-(5-бензилтіазол-2-іл)пропіоамід 10a. Вихід 90 \%. Т.пл. $240-242{ }^{\circ} \mathrm{C}$. Спектр ЯМР ${ }^{1} \mathrm{H}(400 \mathrm{MHz}$, DMSO-d $\left.{ }_{6}\right) \delta: 12.11$ с $(1 \mathrm{H}, \mathrm{NH}), 7.83 \mathrm{c}(1 \mathrm{H},=\mathrm{CH}), 7.66$ д $\left(2 \mathrm{H}, \mathrm{J}=7.2 \mathrm{~Hz}, \mathrm{C}_{6} \mathrm{H}_{5}\right), 7.61-7.53 \mathrm{M}(3 \mathrm{H}, \mathrm{Ar}), 7.36-7.30$ M (2H, Ar), $7.29-7.21 \mathrm{M}\left(4 \mathrm{H}, \mathrm{Ar}, 4-\mathrm{H}_{\text {тіззо }}\right), 4.33 \mathrm{~T}(2 \mathrm{H}, \mathrm{J}$ $\left.=6.8 \mathrm{~Hz}, \mathrm{CH}_{2} \mathrm{~N}\right), 4.09 \mathrm{c}\left(2 \mathrm{H}, \mathrm{PhCH}_{2}\right), 2.82 \mathrm{~T}(2 \mathrm{H}, \mathrm{J}=6.9$ $\left.\mathrm{Hz}, \mathrm{CH}_{2} \mathrm{~N}\right)$

N - ( 5 - б е н 3 и л т і а 3 о л - 2 - і л ) - 3 - [ 5 - ( 4 метилбензиліден)-4-оксо-2-тіоксотіазолідин-3-іл] пропіоамід 10b. Вихід $86 \%$. Т.пл. 242-244 ${ }^{\circ} \mathrm{C}$. Спектр ЯMP ${ }^{1} \mathrm{H}\left(400 \mathrm{MHz}, \mathrm{DMSO}_{-} \mathrm{d}_{6}\right) \delta: 12.08 \mathrm{c}(1 \mathrm{H}$, $\mathrm{NH}), 7.77$ с $(1 \mathrm{H},=\mathrm{CH}), 7.54$ д $\left(2 \mathrm{H}, \mathrm{J}=7.6 \mathrm{~Hz}, \mathrm{C}_{6} \mathrm{H}_{4}\right)$, 7.37 д $\left(2 \mathrm{H}, \mathrm{J}=7.6 \mathrm{~Hz}, \mathrm{C}_{6} \mathrm{H}_{4}\right), 7.33-7.17 \mathrm{~m}\left(6 \mathrm{H}, \mathrm{C}_{6} \mathrm{H}_{5}\right.$, $\left.4-\mathrm{H}_{\text {тіазол }}\right), 4.31 \mathrm{~T}\left(2 \mathrm{H}, \mathrm{J}=6.5 \mathrm{~Hz}, \mathrm{CH}_{2} \mathrm{~N}\right), 4.06 \mathrm{c}\left(2 \mathrm{H}, \mathrm{CH}_{2}\right)$, $2.79 \mathrm{~T}\left(2 \mathrm{H}, \mathrm{J}=6.5 \mathrm{~Hz}, \mathrm{CH}_{2} \mathrm{CO}\right), 2.37 \mathrm{c}\left(3 \mathrm{H}, \mathrm{CH}_{3}\right)$.

N - ( 5 - б е н 3 и л т і а 3 ол - 2 - і л ) - 3 - [ 5 - ( 4 хлоробензиліден)4-оксо-2-тіоксотіазолідин-3-іл] пропіоамід 10с. Вихід 89 \%. Т.пл. 256-258 ${ }^{\circ} \mathrm{C}$. Спектр ЯMP ${ }^{1} \mathrm{H}\left(400 \mathrm{MHz}, \mathrm{DMSO}-\mathrm{d}_{6}\right) \delta: 12.09 \mathrm{c}(1 \mathrm{H}, \mathrm{NH}), 7.82$ с $(1 \mathrm{H},=\mathrm{CH}), 7.67$ д $\left(2 \mathrm{H}, \mathrm{J}=6.9 \mathrm{~Hz}, \mathrm{C}_{6} \mathrm{H}_{4}\right), 7.62$ д $(2 \mathrm{H}, \mathrm{J}$ $\left.=8.1 \mathrm{~Hz}, \mathrm{C}_{6} \mathrm{H}_{4}\right), 7.30$ д $\left(2 \mathrm{H}, \mathrm{J}=6.9 \mathrm{~Hz}, \mathrm{C}_{6} \mathrm{H}_{5}\right), 7.28-$ $7.17 \mathrm{~m}\left(4 \mathrm{H}, \mathrm{C}_{6} \mathrm{H}_{5}, 4-\mathrm{H}_{\text {тіазол }}\right), 4.31 \mathrm{~T}\left(2 \mathrm{H}, \mathrm{J}=7.3 \mathrm{~Hz}, \mathrm{CH}_{2} \mathrm{~N}\right)$, $4.07 \mathrm{c}\left(2 \mathrm{H}, \mathrm{CH}_{2}\right), 2.79 \mathrm{~T}\left(2 \mathrm{H}, \mathrm{CH}_{2} \mathrm{CO}\right)$.

3-(5-Бензиліден-4-оксо-2-тіоксотіазолідин-3іл)-N-[5-(4-метилбензил)-тіазол-2-іл]пропіоамід 10d. Вихід 90 \%. Т.пл. 232-234 ${ }^{\circ} \mathrm{C}$. Спектр ЯМР ${ }^{1} \mathrm{H}$ $\left(400 \mathrm{MHz}, \mathrm{DMSO}-\mathrm{d}_{6}\right) \delta: 12.07 \mathrm{c}(1 \mathrm{H}, \mathrm{NH}), 7.81 \mathrm{c}(1 \mathrm{H}$, $=\mathrm{CH}), 7.64$ д $\left(2 \mathrm{H}, \mathrm{J}=6.7 \mathrm{~Hz}, \mathrm{C}_{6} \mathrm{H}_{5}\right), 7.58-7.51 \mathrm{~m}(3 \mathrm{H}$, $\left.\mathrm{C}_{6} \mathrm{H}_{5}\right), 7.20 \mathrm{c}\left(1 \mathrm{H}, 4-\mathrm{H}_{\text {тіазол }}\right), 7.13$ д $\left(2 \mathrm{H}, \mathrm{J}=7.9 \mathrm{~Hz}, \mathrm{C}_{6} \mathrm{H}_{4}\right)$, 7.11 д $\left(2 \mathrm{H}, J=7.9 \mathrm{~Hz}, \mathrm{C}_{6} \mathrm{H}_{4}\right), 4.31 \mathrm{~T}(2 \mathrm{H}, J=6.6 \mathrm{~Hz}$, $\left.\mathrm{CH}_{2} \mathrm{~N}\right), 4.01 \mathrm{c}\left(2 \mathrm{H}, \mathrm{CH}_{2}\right), 2.80 \mathrm{~T}\left(2 \mathrm{H}, \mathrm{J}=6.4 \mathrm{~Hz}, \mathrm{CH}_{2} \mathrm{CO}\right)$, $2.26 \mathrm{C}\left(3 \mathrm{H}, \mathrm{CH}_{3}\right)$.

3 - [ 5 - ( 4 - Ме т и лбе н 3 ил іден ) - 4 - о к с о - 2 тіоксотіазолідин-3-іл]-N-[-[5-(4-метилбензил)тіазол-2-іл]пропіоамід 10е. Вихід 97 \%. Т.пл. 239$241{ }^{\circ} \mathrm{C}$. Спектр ЯMP ${ }^{1} \mathrm{H}\left(400 \mathrm{MHz}, \mathrm{DMSO}-\mathrm{d}_{6}\right) \delta: 12.06$ с $(1 \mathrm{H}, \mathrm{NH}), 7.77$ с $(1 \mathrm{H},=\mathrm{CH}), 7.53$ д $(2 \mathrm{H}, \mathrm{J}=7.8 \mathrm{~Hz}$, $\left.\mathrm{C}_{6} \mathrm{H}_{4}\right), 7.37$ д $\left(2 \mathrm{H}, \mathrm{J}=7.9 \mathrm{~Hz}, \mathrm{C}_{6} \mathrm{H}_{4}\right), 7.19 \mathrm{c}\left(1 \mathrm{H}, 4-\mathrm{H}_{\text {тіазол }}\right)$, 7.13 д $\left(2 \mathrm{H}, \mathrm{J}=7.8 \mathrm{~Hz}, \mathrm{C}_{6} \mathrm{H}_{4}\right), 7.10$ д $(2 \mathrm{H}, \mathrm{J}=7.7 \mathrm{~Hz}$, $\left.\mathrm{C}_{6} \mathrm{H}_{4}\right), 4.31 \mathrm{~T}\left(2 \mathrm{H}, \mathrm{J}=6.8 \mathrm{~Hz}, \mathrm{CH}_{2} \mathrm{~N}\right), 4.01 \mathrm{c}\left(2 \mathrm{H}, \mathrm{CH}_{2}\right)$, 
Синтез біологічно активних сполук

Synthesis of biologically active compounds

$2.79 \mathrm{~T}\left(2 \mathrm{H}, \mathrm{J}=6.8 \mathrm{~Hz}, \mathrm{CH}_{2} \mathrm{CO}\right), 2.37 \mathrm{c}\left(3 \mathrm{H}, \mathrm{CH}_{3}\right), 2.26 \mathrm{c}$ $\left(3 \mathrm{H}, \mathrm{CH}_{3}\right)$.

3 - [ 5 - ( 4 - Х л о робе н 3 и лід ен ) - 4 - о к с о - 2 тіоксотіазолідин-3-іл]-N-[5-(4-метилбензил)-тіазол2-іл]пропіоамід 10f. Вихід 98 \%. Т.пл. 257-259 ${ }^{\circ} \mathrm{C}$. Спектр ЯМР ${ }^{1} \mathrm{H}(400 \mathrm{MHz}$, DMSO-d $) \delta: 12.07 \mathrm{c}(1 \mathrm{H}$, $\mathrm{NH}), 7.82$ с $(1 \mathrm{H},=\mathrm{CH}), 7.67$ д $\left(2 \mathrm{H}, \mathrm{J}=8.5 \mathrm{~Hz}, \mathrm{ClC}_{6} \mathrm{H}_{4}\right)$, 7.62 д $\left(2 \mathrm{H}, \mathrm{J}=8.4 \mathrm{~Hz}, \mathrm{ClC}_{6} \mathrm{H}_{4}\right), 7.20$ с $\left(1 \mathrm{H}, 4-\mathrm{H}_{\text {тізоло }}\right), 7.13$ д $\left(2 \mathrm{H}, \mathrm{J}=8.0 \mathrm{~Hz}, \mathrm{MeC}_{6} \mathrm{H}_{4}\right), 7.11$ д $(2 \mathrm{H}, \mathrm{J}=7.7 \mathrm{~Hz}$, $\left.\mathrm{MeC}_{6} \mathrm{H}_{4}\right), 4.31 \mathrm{~T}\left(2 \mathrm{H}, \mathrm{J}=6.7 \mathrm{~Hz}, \mathrm{CH}_{2} \mathrm{~N}\right), 4.01 \mathrm{C}\left(2 \mathrm{H}, \mathrm{CH}_{2}\right)$, $2.79 \mathrm{~T}\left(2 \mathrm{H}, \mathrm{J}=6.5 \mathrm{~Hz}, \mathrm{CH}_{2} \mathrm{CO}\right), 2.26 \mathrm{c}\left(3 \mathrm{H}, \mathrm{CH}_{3}\right)$.

3-(5-Бензиліден-4-оксо-2-тіоксотіазолідин-3іл)-N-[5-(4-хлоробензил)-тіазол-2-іл]]пропіоамід 10g. Вихід 98 \%. Т.пл. 245-247 ${ }^{\circ} \mathrm{C}$. Спектр ЯМР ${ }^{1} \mathrm{H}$ $\left(400 \mathrm{MHz}, \mathrm{DMSO}-\mathrm{d}_{6}\right) \delta: 12.11 \mathrm{c}(1 \mathrm{H}, \mathrm{NH}), 7.81 \mathrm{c}(1 \mathrm{H}$, $=\mathrm{CH}), 7.64$ д $\left(2 \mathrm{H}, \mathrm{J}=6.9 \mathrm{~Hz}, \mathrm{C}_{6} \mathrm{H}_{5}\right), 7.60-7.48 \mathrm{~m}(3 \mathrm{H}$, $\left.\mathrm{C}_{6} \mathrm{H}_{5}\right), 7.36$ д $\left(2 \mathrm{H}, \mathrm{J}=8.2 \mathrm{~Hz}, \mathrm{C}_{6} \mathrm{H}_{4}\right), 7.28$ д $(2 \mathrm{H}, \mathrm{J}=8.2$ $\left.\mathrm{Hz}, \mathrm{C}_{6} \mathrm{H}_{4}\right), 7.23 \mathrm{C}\left(1 \mathrm{H}, 4-\mathrm{H}_{\text {тіззол }}\right), 4.32 \mathrm{~T}(2 \mathrm{H}, \mathrm{J}=6.9 \mathrm{~Hz}$, $\left.\mathrm{CH}_{2} \mathrm{~N}\right), 4.07 \mathrm{c}\left(2 \mathrm{H}, \mathrm{CH}_{2}\right), 2.80 \mathrm{~T}\left(2 \mathrm{H}, \mathrm{J}=6.9 \mathrm{~Hz}, \mathrm{CH}_{2} \mathrm{CO}\right)$.

N-[5-(4-хлоробензил)-тіазол-2-іл]-3-[5-(4метилбензиліден)-4-оксо-2-тіоксотіазолідин-3-іл] пропіоамід 10h. Вихід 72 \%. Т.пл. 238-240 ${ }^{\circ} \mathrm{C}$. Спектр ЯMP ${ }^{1} \mathrm{H}\left(400 \mathrm{MHz}, \mathrm{DMSO}^{\left.-\mathrm{d}_{6}\right)} \delta: 12.11 \mathrm{c}(1 \mathrm{H}\right.$, $\mathrm{NH}), 7.77$ с $(1 \mathrm{H},=\mathrm{CH}), 7.54$ д $\left(2 \mathrm{H}, \mathrm{J}=7.9 \mathrm{~Hz}, \mathrm{MeC}_{6} \mathrm{H}_{4}\right)$, 7.38 д $\left(2 \mathrm{H}, \mathrm{J}=7.9 \mathrm{~Hz}, \mathrm{MeC}_{6} \mathrm{H}_{4}\right), 7.36$ д $(2 \mathrm{H}, \mathrm{J}=8.2 \mathrm{~Hz}$, $\left.\mathrm{ClC}_{6} \mathrm{H}_{4}\right), 7.28$ д $\left(2 \mathrm{H}, \mathrm{J}=8.2 \mathrm{~Hz}, \mathrm{ClC}_{6} \mathrm{H}_{4}\right), 7.22 \mathrm{c}(1 \mathrm{H}$, $\left.4-\mathrm{H}_{\text {тізол }}\right), 4.31 \mathrm{~T}\left(2 \mathrm{H}, \mathrm{J}=6.9 \mathrm{~Hz}, \mathrm{CH}_{2} \mathrm{~N}\right), 4.07 \mathrm{c}\left(2 \mathrm{H}, \mathrm{CH}_{2}\right)$, $2.80 \mathrm{~T}\left(2 \mathrm{H}, \mathrm{J}=6.8 \mathrm{~Hz}, \mathrm{CH}_{2} \mathrm{CO}\right), 2.37 \mathrm{c}\left(3 \mathrm{H}, \mathrm{CH}_{3}\right)$.

3 - [ 5 - ( 4 - Х ло р о бе н з и лі де н ) - 4 - о кс о - 2 тіоксотіазолідин-3-іл]-N-[5-(4-хлоробензил)тіазол-2-іл]пропіоамід 10і. Вихід 99 \%. Т.пл. 241$243^{\circ} \mathrm{C}$. Спектр ЯМР ${ }^{1} \mathrm{H}\left(400 \mathrm{MHz}, \mathrm{DMSO}-\mathrm{d}_{6}\right) \delta: 12.11$ с $(1 \mathrm{H}, \mathrm{NH}), 7.81$ с $(1 \mathrm{H},=\mathrm{CH}), 7.67$ д $(2 \mathrm{H}, \mathrm{J}=8.6 \mathrm{~Hz}$, $\left.\mathrm{C}_{6} \mathrm{H}_{4}\right), 7.62$ д $\left(2 \mathrm{H}, \mathrm{J}=8.5 \mathrm{~Hz}, \mathrm{C}_{6} \mathrm{H}_{4}\right), 7.36$ д $(2 \mathrm{H}, \mathrm{J}=8.3$ $\left.\mathrm{Hz}, \mathrm{C}_{6} \mathrm{H}_{4}\right), 7.28$ д $\left(2 \mathrm{H}, \mathrm{J}=8.1 \mathrm{~Hz}, \mathrm{C}_{6} \mathrm{H}_{4}\right), 7.23 \mathrm{c}(1 \mathrm{H}$, $\left.4-\mathrm{H}_{\text {тіазол }}\right), 4.31 \mathrm{~T}\left(2 \mathrm{H}, \mathrm{J}=6.8 \mathrm{~Hz}, \mathrm{CH}_{2} \mathrm{~N}\right), 4.07 \mathrm{c}\left(2 \mathrm{H}, \mathrm{CH}_{2}\right)$, $2.80 \mathrm{~T}\left(2 \mathrm{H}, \mathrm{J}=7.1 \mathrm{~Hz}, \mathrm{CH}_{2} \mathrm{CO}\right)$.
Методика дослідження антимікробної активності

Антимікробну активність отриманих сполук вивчали за допомогою мікрометоду з використанням одноразових 96-лункових стерильних полістиролових планшет та мікротитраторів Такачі. Тест-штами бактерій вирощували протягом 18 - 20 год на скошеному м'ясо-пептонному агарі (МПА) при температурі $+37^{\circ}$ С. При вивченні чутливості штаму B.subtilis ATCC № 6633 використовували суспензію спор цієї бактерії. Грибки культивували в рідкому середовищі Сабуро 18 - 20 год при температурі $+30^{\circ}$ С. 3 отриманих культур готували суспензії 3 оптичною густиною 0.5 одиниці Макфарланда. Для цього використано денситометер DEN-1. Отримані вихідні суспензії розведені до робочої концентрації, яка була близькою до $1 \cdot 10^{3}$ колонієутворюючих одиниць (КУО) в 1 мл, 3 використанням рідких поживних середовищ - поживного бульйону з пептоном (ПБ) (для бактерій) та рідкого середовища Сабуро (для грибків). 3 метою контролю правильності виготовлення робочих суспензій з них робили висіви на МПА (для бактерій) та на тверде середовище Сабуро (у випадку грибків) у чашках Петрі. Для кожної суспензії виконували два паралельні висіви. Чашки інкубувались при $+37^{\circ} \mathrm{C}$ 18 - 20 год (для бактерій) та при $+30^{\circ}$ C $42-44$ години (для грибків), після чого проводився підрахунок кількості колоній, які виросли, з наступним розрахунком концентрацій тест-штамів у робочих суспензіях.

У лунки одноразового стерильного полістиролового планшету вносили по 0.05 мл робочих суспензій. За допомогою титраторів Такачі готували розведення досліджуваних речовин від 1:1 (500 мкг/мл) до 1:256 (3,9 мкг/мл).

Планшети з тест-штамами бактерій інкубували у вологій камері при $\mathrm{t}^{0}+37^{\circ} \mathrm{C}$ протягом $18-20$ год, 3 тест-штамами грибків при $\mathrm{t}^{\circ}+30^{\circ} \mathrm{C}$ протягом $42-$ 44 год, після чого проведено облік результатів.

\title{
СИНТЕЗ И АНТИМИКРОБНЫЕ СВОЙСТВА 5-(4-R-БЕНЗИЛ)-2-ТИАЗОЛИЛАМИДОВ 5-АРИЛИДЕНРОДАНИН-3-АЛКАНКАРБОНОВЫХ КИСЛОТ
}

\author{
Д. А. Фролов ${ }^{1}$, В. Я. Горишнийㄹ, О. О. Блиндер ${ }^{3}$, Ю. В. Остапюк ${ }^{1}$, В. С. Матийчук ${ }^{1}$ \\ Львовский национальный университет имени Ивана Франко \\ Львовский национальный медицинский университет имени Данила Галицкого ${ }^{2}$ \\ ГВУз Украины «Буковинский медицинский университет» \\ matichyk@mail.Iviv.ua
}

Цель работы. Синтез N-[5-(4-R-бензил)тиазол-2-ил]-2-[5-(4-R 1 -бензилиден)-4-оксо-2-тиоксотиазолидин-3-ил]ацети пропионамидов с дальнейшим исследованием их антимикробной активности.

Материалы и методы. При выполнении экспериментальной части работы использованы традиционные методы органического синтеза. Спектры ЯMP полученных соединений снимались на приборе Varian VXR-400,

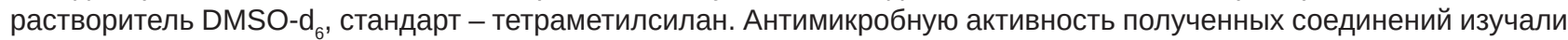
с помощью микрометода с использованием одноразовых 96-луночных стерильных полистироловых планшетов и микротитраторов Такача.

ISSN 2312-0967. Фармацевтичний часопис. 2017. № 3 
Результаты и обсуждение. Взаимодействием 5-(4-R-бензил)-1,3-тиазол-2-аминов 1a-c с хлорангидридами (5-R ${ }^{1-}$ бензилиден-4-оксо-2-тиоксотиазолидин-3-ил)уксусной 7a-c и пропионовой кислот 8а-с получен ряд новых амидов 9a-i та 10a-i. Исследована их антимикробная активность. Установлено, что соединения 9а и 10h обладают высокой активностью в отношении S.aureus ATCC № 25923.

Выводы. Впервые получен ряд N-[5-(4-R-бензил)тиазол-2-ил]-2-[5-(4-R¹-бензилиден)-4-оксо-2-тиоксотиазолидин3-ил]ацет- и пропионамидов, исследована in vitro их антимикробная активность. Найдены соединения, обладающие высокой активностью в отношении S.aureus ATCC № 25923.

Ключевые слова: тиазол; 2-тиоксотиазолидин-4-он; хлорарилирование; антимикробная активность.

\title{
SYNTHESIS AND ANTIMICROBIAL PROPERTIES OF 5-(4-R-BENZYL)THIAZOLYLAMIDES OF 5-ARYLIDENERHODANINE-3-ALKANCARBOXYLIC ACIDS
}

\author{
D. A. Frolov ${ }^{1}$, V. Ya. Horishny², O. O. Blinde ${ }^{3}$, Yu. V. Ostapiuk ${ }^{1}$, V. S. Matiychuk ${ }^{1}$ \\ Ivan Franko Lviv National University ${ }^{1}$ \\ Danylo Halytsky Lviv National Medical University² \\ Bukovyna State Medical University ${ }^{3}$ \\ matichyk@mail.Iviv.ua
}

The aim of the work. Synthesis of 5-(4-R-benzyl)thiazol-2-yl]-2-[5-(4-R ${ }^{1}$-benzylidene)-4-oxo-2-thioxothiazolidin-3-yl]acetand propionamides and study of their antimicrobial activity.

Materials and Methods. Traditional methods of organic synthesis during performing of experimental part were used. The ${ }^{1} \mathrm{H}$ and ${ }^{13} \mathrm{C}$ NMR spectra of the synthesized compounds were recorded on a Varian VXR-400 instrument, DMSO- $d_{6}$ solvent, tetramethylsilane standard. The antimicrobial activity of the synthesized compounds was studied using a micromethod using single-use 96-well sterile polystyrene tablets and Takachi microtracters.

Results and Discussion. A raw of novel N-[5-(4-R-benzyl) thiazol-2-yl]-2-[5-(4-R ${ }^{1}$-benzylidene)-4-oxo-2-thioxotiazolidin-3$\mathrm{yl}$ ]acet- and propionamides were prepared by the reaction of 5-(4-R-benzyl)-1,3-thiazole-2-amines with (5-R ${ }^{1}$-benzylidene4-oxo-2-thioxotiazolidin-3-yl)acetic- and propionic acid chlorides. The antimicrobial activity of synthesized compounds was investigated. We established that compounds 9a and 10h showed activity against to S.aureus ATCC No. 25923.

Conclusions. A series of new N-[5-(4-R-benzyl)thiazol-2-yl]-2-[5-(4-R ${ }^{1}$-benzylidene)-4-oxo-2-thioxotiazolidin-3-yl]acetand propionamides and their in vitro antimicrobial activity was studied.

Compounds with high activity against to S. aureus ATCC No. 25923 were found.

Key words: 2-aminothiazole; 2-thioxothiazolidin-4-one; chloroarylation; antimicrobial activity.

\section{Список літератури}

1. Nevagi R. J. Biological and medicinal significance of 2-aminothiazoles / R. J. Nevagi // Pharm. Let. - 2014. Vol. 6, № 5. - P. 134-150.

2. Das Debasis. Recent developments of 2-aminothiazoles in medicinal chemistry / Debasis Das, Papiya Sikdar, Moumita Bairagi // Eur. J. Med. Chem. - 2016. - Vol. 109. P. 89-98.

3. Girish Kumar Gupta. Thiazole: A privileged scaffold in drug discovery / Girish Kumar Gupta, Vinod Kumar Walter de Gruyter $\mathrm{GmbH} \&$ Co KG // Chemical Drug Design. 2016. $-297 \mathrm{p}$

4. Thiazole: A review on chemistry, synthesis and therapeutic importance of its derivatives / M. T. Chhabria, S. Patel, P. Modi [et al.] // Curr. Top Med. Chem. - Vol. 16, Iss. 26. - 2016. - P. 2841-2862.

5. Лекарственные средства / [М. Д. Машковский]. - М. : Новая волна, 2010. - 1216 с.

6. Tomasić T. Rhodanine as a privileged scaffold in drug discovery / T. Tomasić, L. P. Masic // Curr. Med. Chem. 2009. - Vol. 16, № 13. - P. 1596-1629.
7. Обушак Н. Д. Синтез гетероциклов на основе продуктов арилирования непредельных соединений. Х. 3-Арил-2-хлорпропанали - реагенты для синтеза производных 2-амино-1,3-тиазола / Н. Д. Обушак, В. С. Матийчук, Р. Я. Васылышин и др. // Журн. орган. хим. - 2004. - Т. 40, Вып. 3. - С. 412-417; Russ. J. Org. Chem. - 2004. - Vol. 40, № 3. - P. 383-389.

8. Subhedar D. D. [Et3NH][HSO4] catalyzed efficient synthesis of 5-arylidene-rhodanine conjugates and their antitubercular activity / D. D. Subhedar, M. H. Shaikh, L. Nawale, et al. // Research on Chemical Intermediates. - 2016. Vol. 42, № 8. - P. 6607-6626.

9. Synthesis and biological evaluation of 5-benzylidenerhodanine-3-acetic acid derivatives as AChE and 15-LOX inhibitors / N. Shafii, M. Khoobi, M. Amini [et al.] // Journal of Enzyme Inhibition and Medicinal Chemistry. - 2015. Vol. 30, № 3. - P. 389-395.

10. Facile synthesis of 5-benzylidene rhodamine derivatives under microwave irradiation / J. Zhou, Y. Song, F. Zhu [et al.] // Synthetic Communications. - 2006. - Vol. 36, № 22. - P. 3297-3303.

ISSN 2312-0967. Pharmaceutical review. 2017. № 3 
Синтез біологічно активних сполук

Synthesis of biologically active compounds

\section{References}

1. Nevagi RJ. Biological and medicinal significance of 2-aminothiazoles. Pharm. Let. 2014;6(5):134-50.

2. Debasis Das, Papiya Sikdar, Moumita Bairagi. Recent developments of 2-aminothiazoles in medicinal chemistry. Eur J Med Chem. 2016;109(15): 89-98.

3. Girish Kumar Gupta, Vinod Kumar Walter de Gruyter $\mathrm{GmbH} \& \mathrm{Co} \mathrm{KG}$. Thiazole: A privileged scaffold in drug discovery. Chemical Drug Design. 2016:297.

4. Chhabria MT, Patel S, Modi P, Brahmkshatriya PS. Thiazole: A review on chemistry, synthesis and therapeutic importance of its derivatives. Curr Top Med Chem. 2016;16(26): 2841-62.

5. Mashkovsky MD. Medicinal products. [Лекарственные средства]. М.: Новая волна;2010: 1216. Russian.

6. Tomasić T, Masic LP. Rhodanine as a privileged scaffold in drug discovery. Curr. Med. Chem. 2009;16(13): 1596629.

7. Obushak ND, Matiichuk VS, Vasylyshin RYa, Ostapyuk YuV.
[Heterocyclic syntheses on the basis of arylation products of unsaturated compounds: X. 3-Aryl-2-chloropropanals as reagents for the synthesis of 2-amino-1,3-thiazole derivatives]. Russ J Org Chem. 2004;40(3): 383-9. Russian.

8. Subhedar DD, Shaikh MH, Nawale L, Yeware A, Sarkar D, Shingate BB. [Et3NH][HSO4] catalyzed efficient synthesis of 5-arylidene-rhodanine conjugates and their antitubercular activity. Research on Chemical Intermediates. 2016;42(8): 6607-26.

9. Shafii N, Khoobi M, Amini M, Sakhteman A, Nadri H, Mo$\operatorname{radi} A$, et al. Synthesis and biological evaluation of 5-benzylidenerhodanine-3-acetic acid derivatives as AChE and 15-LOX inhibitors. Journal of Enzyme Inhibition and Medicinal Chemistry. 2015;30(3): 389-95.

10. Zhou JF, Song YZ, Zhu FX, Zhu YL. Facile synthesis of 5-benzylidene rhodamine derivatives under microwave irradiation. Synthetic Communications. 2006;36(22): 3297303.

Отримано 11.07.2017 